OPEN ACCESS

Edited by:

Xiaohui Zhou,

Fudan University, China

Reviewed by:

Tao Shen,

Peking University, China

Bin Su,

Capital Medical University, China

${ }^{*}$ Correspondence:

Yuhong Wang

yuhongwang@gmail.com

Qiang We

weiqiang@cnilas.pumc.edu.cn

Jing Xue

xuejing@cnilas.org

Specialty section:

This article was submitted to

Virology,

a section of the journal

Frontiers in Microbiology

Received: 03 May 2021

Accepted: 21 June 2021

Published: 19 July 2021

Citation:

Tong L, Cong Z, Tian L, Zhang J, Lu J, Lu Q, Chen T, Wang Y, Wei Q and Xue J (2021) Stage-Dependent Within-Individual Comparison Reveals

SIV-Specific Activation/Exhaustion

Shift in Rhesus Macaques.

Front. Microbiol. 12:704449.

doi: 10.3389/fmicb.2021.704449

\section{Stage-Dependent Within-Individual Comparison Reveals SIV-Specific Activation/Exhaustion Shift in Rhesus Macaques}

Ling Tong ${ }^{1}$, Zhe Cong ${ }^{1}$, Long Tian', Jingjing Zhang ${ }^{1}$, Jiahan Lu ${ }^{1}$, Qiuhan Lu ${ }^{1}$, Ting Chen ${ }^{1}$, Yuhong Wang ${ }^{2 *}$, Qiang Wei1,3* and Jing Xue ${ }^{1,3 *}$

${ }^{\prime}$ Key Laboratory of Human Disease Comparative Medicine, Chinese Ministry of Health, Beijing Key Laboratory for Animal Models of Emerging and Remerging Infectious Diseases, Institute of Laboratory Animal Science, Chinese Academy of Medical Sciences and Comparative Medicine Center, Peking Union Medical College, Beijing, China, ${ }^{2}$ Department of Gerontology and Geriatrics, The First Affiliated Hospital of Harbin Medical University, Harbin, China, ${ }^{3}$ Center for AIDS Research, Chinese Academy of Medical Sciences, Beijing, China

It is challenging to trace the complicated individual-based variations of HIVspecific immunocompetence shift during the successful antiretroviral therapy (ART) era. Using eight rhesus monkeys simulating a longitudinal stage-dependent cohort (baseline-SIV acute infection-SIV suppression by ART-ART withdrawal), baseline immunocompetence monitoring for 28 days (SIV-negative stage, SN) was compared with host immunocompetence undergoing 90-day ART treatment (SIV-suppressed stage, SS) to reveal the SIV-specific immunity shift aroused by undetectable individual viral replication. During acute SIV infection for 98 days (SIV-emerged stage, SE), immune activation was compared with re-immune activation post ART for 49-day follow-up (SIVrebounded stage, SR) to reveal the SIV-specific immune activation variation aroused by detectable individual viral replication. Individual immunocompetence was measured by co-expression of CD4, CD8, CD38, HLA-DR, CCR7, CD45RA, and PD-1 on T cells and a cytokine panel. Compared with $\mathrm{SN}$, mild immune activation/exhaustion was

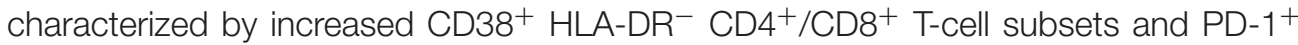
memory $\mathrm{CD}^{+} / \mathrm{CD}^{+}{ }^{+}$T-cell subsets with three elevated cytokines (MIP-1 $\beta, \mathrm{IL}-8$, and $\mathrm{IL}-10)$ significantly emerged in SS. Compared with SE, SR produced more exhaustion characterized by increased PD-1+ $\mathrm{CD} 4{ }^{+} \mathrm{T}_{\mathrm{CM}}$ cells and decreased PD-1+ $\mathrm{CD} 4{ }^{+} \mathrm{T}_{\mathrm{EM}}$ cells with four elevated pro-inflammatory cytokines (IFN- $\gamma, I L-1 \beta, I L-6$, and TNF- $\alpha$ ). By such individualized stage-dependent comparison, the sustainable immune activation was found from activation/exhaustion shifted into exhaustion during the longitudinal viral persistence. Further, validated SIV accelerates host immunosenescence continuously independent of viral replication.

Keywords: HIV/SIV, rhesus macaques, activation, exhaustion, stage-dependent comparison 


\section{INTRODUCTION}

As one of the most significant public problems, human immunodeficiency virus type-1 (HIV-1) infection is now associated with long-term subclinical survival due to successful antiretroviral therapy (ART). Acute HIV infection activates $\mathrm{CD}^{+} \mathrm{T}$ cells to produce high level systematic inflammation against viral expansion (Douek, 2013; Paiardini and Müller-Trutwin, 2013). Simultaneously, such inflammatory cytokines accelerate $\mathrm{CD}^{+}$T-cell apoptosis and disturb the immunocompetence balance to progress to immunity deficiency. Despite that, successful ART could draw the host from acute $\mathrm{HIV}$-specific $\mathrm{CD}^{+}$T-cell activation cascade into an undetectable antigenic presentation and very low response, the "invisible" latency sustainably arouses immunologic activation/exhaustion of memory $\mathrm{T}$ cells, the process of which is similar to normal aging (Appay et al., 2007; Pathai et al., 2014). Three attenuated mechanisms on antigen-specific immunity competence, including clonal deletion, functional unresponsiveness (exhaustion), and viral persistence with evaded recognition, were simultaneously studied on chronic ART-treated HIV patients (Goepfert et al., 2000; Goulder et al., 2000; Kostense et al., 2001, 2002). Among them, exhaustion remarkedly showed overexpressed checkpoint makers, particularly programmed death 1 (PD1) (Brenchley et al., 2006). Elevated PD-1 expression on HIV-specific $\mathrm{CD}^{+} \mathrm{T}$ cells plays the role of exhaustion mediator of $\mathrm{CD}^{+} \mathrm{T}$ cells to reduce cytokine production and proliferation (Kaufmann and Walker, 2008). Interestingly, PD-1 upregulation linearly correlates with HIV-specific memory $\mathrm{CD}^{+}$T-cell exhaustion in the acute infection stage but not in long-term non-progressors (Zhang et al., 2007), indicating that chronic virus-host molecular interaction could be more complicated and subtle corresponding to viral persistence. Increasing proofs indicate that continuous high expression of immunoregulatory markers, including PD-1 and other checkpoint receptors, supports sustainable activation/exhaustion during chronic viral persistence (Day et al., 2006; Kaufmann and Walker, 2008).

However, in the context of immunocompetence imbalance, it has not been determined how exhausted T cells end to apoptosis or regain mild activation (Zhang et al., 2007; Youngblood et al., 2013; Hoffmann et al., 2016; Muenchhoff et al., 2019). These differentiation-independent activation/exhaustion/apoptosis are of high between-host heterogeneity (Zhang et al., 2007; Petrovas et al., 2009; Youngblood et al., 2013; Muenchhoff et al., 2019). Moreover, HIV-specific immune activation and $\mathrm{CD}^{+}$ $\mathrm{T}$ cytotoxic response in $\mathrm{HIV}$-undetectable status are different between ART-treated individuals and "primed" elite controllers (Sáez-Cirión and Sereti, 2021). As antigen presentation provides costimulatory signals to maintain $\mathrm{CD} 8^{+} \mathrm{T}$-cell polyfunctionality to resist apoptosis, ART treatment reduces polyfunctionality due to decreased antigenic stimulation instead of stabilization on T-cell perturbation. These $\mathrm{CD}^{+} \mathrm{T}$ cells present a low cytotoxic response against $\mathrm{HIV}$ and high susceptibility to apoptosis, as apoptosis-resistant $\mathrm{CD}^{+} \mathrm{T}$ cells isolated from elite controllers are primed to control HIV replication (Lichterfeld et al., 2007; Streeck et al., 2009). Therefore, the individualbased host-virus interaction shift cannot be achieved by comparing ART-treated HIV carriers and HIV-controlled elite patients due to "primed" genetic variation. The best strategy to reveal such eventual immunocompetence shift from dominant immune activation into sustainable activation/exhaustion until exhaustion/senescence during HIV infection is to monitor the baseline immunity before individual infection. Moreover, longitudinal studies show the global shift from robustness into exhaustion due to attenuated antigen presentation binding costimulatory signals (van der Most et al., 2003). However, such chronic exhaustion does not equate to irreversible termination or deletion. Some exhausted $\mathrm{CD}^{+} \mathrm{T}$ cells could circulate long in the peripheral blood with compromised yet sustained polyfunctionality, highly similar to immunosenescent phenotypes (Cao et al., 2016; Martínez-Zamudio et al., 2021).

HIV latency-dependent persistence promotes similar T-cell phenotype shift to normal aging (Deeks, 2011) as chronic low-level inflammatory activation also termed as "inflammaging" (Monti et al., 2017). One of the attributive pathogens is cytomegalovirus (CMV), considered responsible for the T-cell immune activation and exhaustion by aging in the general population. Notably, subclinical HIV carriers are more susceptible to age-related cardiovascular disease, metabolic disorders, neurocognitive decline, and cancers due to T-cell immunosenescence (Hansson, 2005; Deeks et al., 2013; van den Dries et al., 2017). From this aspect, HIV persistence is regarded as accelerated immunosenescence (Appay et al., 2007; Molina-Pinelo et al., 2009; Dock and Effros, 2011; Pathai et al., 2014). A bundle of proofs indicates that old asymptomatic HIV carriers who have undergone successful long-term ART harbor heavier loads of aging-related diseases compared with their agegender matches (Schouten et al., 2014; Appay and Sauce, 2017). Notably, CMV, regarded as the responsible antigen for "natural" immunity aging, does not aggravatedly compromise the CD8 ${ }^{+}$ T-cell response as HIV does within the same host (Naeger et al., 2010). However, chronic CMV persistence contributes to more accumulation of immunosenescence and inflammation than HIV does within the same host (Booiman et al., 2017). Such CMVHIV co-persistence further aggravates the complexity of chronic HIV immunity reconstitution. Within-individual comparison is required to find the optimal balance between antigen-dependent costimulatory signals and effective cytokine signals during an individualized scenario.

Using our individual-based comparison, we attempt to differentiate the overlapped process between T-cell exhaustion and activation and reveal the potentially optimal balance of activation/exhaustion/senescence along with the individual scenario. In the present study, we overtook baseline profiling to "replace" conventional elite controllers, which could adjust residual immunocompetence to achieve within-individual differences before and after ART. We attempt to reveal the immunocompetence shift from host-virus interaction. Also, we compared differences between acute infection and ARTceased rebound to replenish the "additional" shift of the imbalance of immunity activation/exhaustion/senescence during SIV infection. 


\section{MATERIALS AND METHODS}

\section{Study Design}

Eight 4-6-year-old, male and female pathogen-free (SPF) rhesus monkeys (Macaca mulatta) were housed and cared for following the Institutional Animal Care and Use Committee (IACUC) of the Institute of Laboratory Animal Science and the recommendations of the Weatherall report for the use of nonhuman primates in research ${ }^{1}$ at the Association for Assessment and Accreditation of Laboratory Animal Care (AAALAC)accredited facility. Macaques were intravenously infected with 100 tissue culture infective doses $\left(\right.$ TCID $_{50}$ ) of SIVmac239 as

${ }^{1} \mathrm{http} / /$ www.acmedsci.ac.uk/more/news/the- use- of-non-human-primates-inresearch/ described (Chong et al., 2019). All animal procedures and experiments were performed following protocols approved by the IACUC of the Institute of Laboratory Animal Science, Chinese Academy of Medical Sciences (No. XJ19005). All animals were anesthetized with ketamine hydrochloride $(10 \mathrm{mg} / \mathrm{kg})$ before sample collection, and experiments were performed in a biosafety level 3 laboratory.

Antiretroviral therapy was initiated 98 days after infection and continued for 3 months. The ART regimen consisting of two reverse transcriptase inhibitors, $5 \mathrm{mg} / \mathrm{ml}$ tenofovir disoproxil fumarate (TDF) and $40 \mathrm{mg} / \mathrm{ml}$ emtricitabine (FTC), plus $2.5 \mathrm{mg} / \mathrm{ml}$ of the integrase inhibitor dolutegravir (DTG), was subcutaneously administered once daily at $1 \mathrm{ml} / \mathrm{kg}$ body weight (Whitney et al., 2018). The eight monkeys were followed up 49 days after discontinuation of ART. As part of the longitudinal
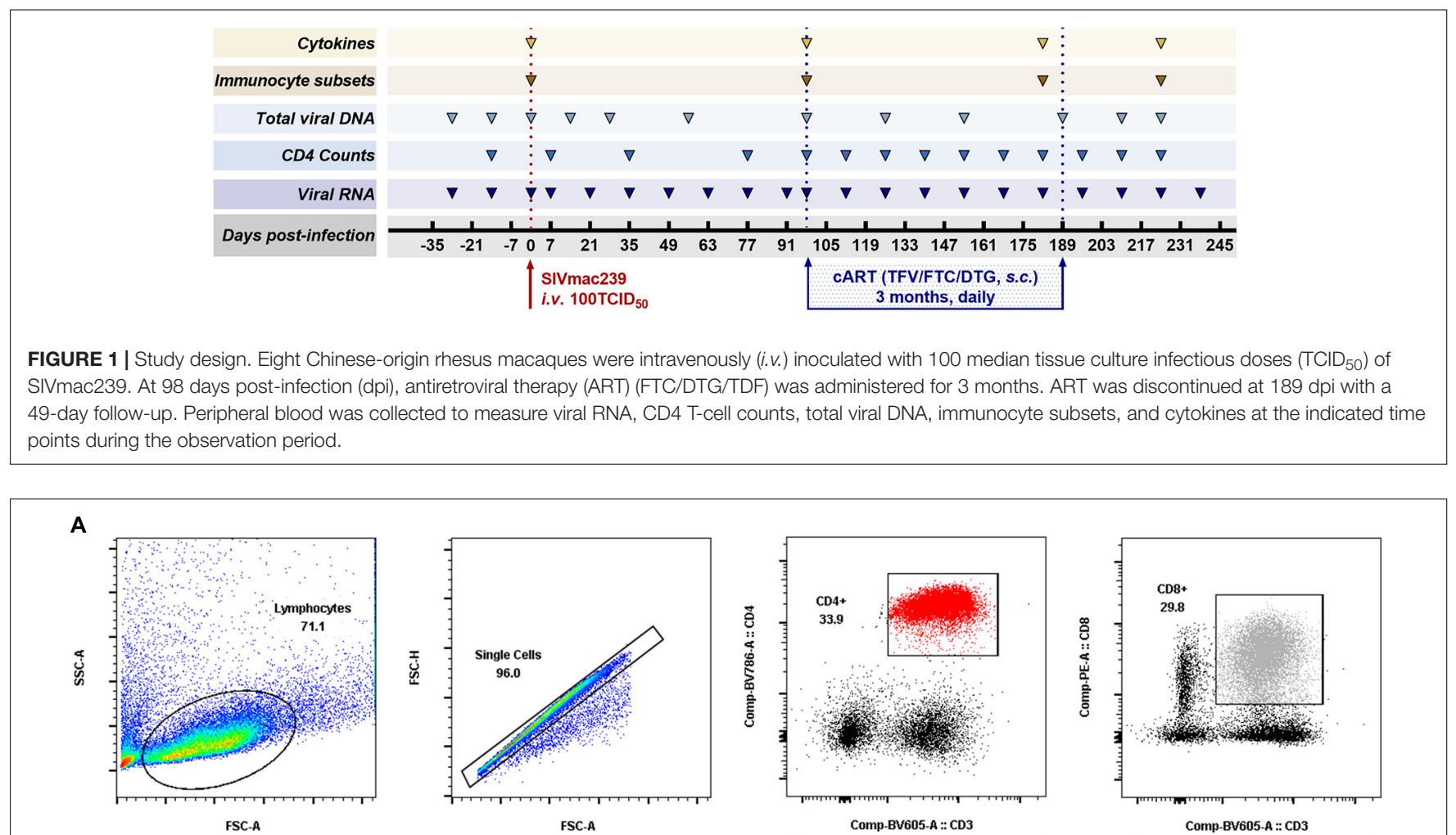

Comp-BV605-A : : CD3
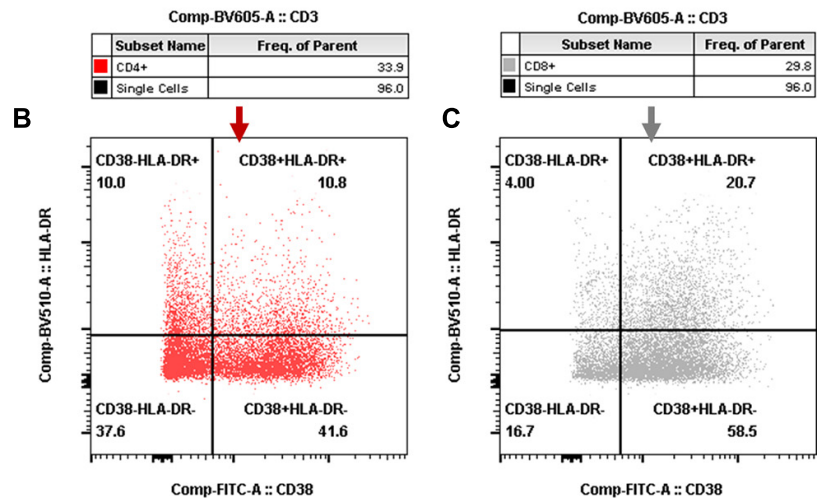

FIGURE 2 | Gating for activated T-cell populations by flow cytometry. (A) Gating for CD4 ${ }^{+}$T cells (red dot plot in the rectangle) and CD8 ${ }^{+} \mathrm{T}$ cells (gray dot plot in the rectangle). (B,C) Gating for activated CD4 ${ }^{+}$T-cell subsets (B) and activated CD8 ${ }^{+}$T-cell subsets (C) with CD38 and/or HLA-DR expression. 
observation, the effect of SIV RNA and total viral DNA on CD4 T-cell counts, immunocyte subsets, and cytokines was measured at the indicated time points (Figure 1).

\section{Quantification of SIV RNA and Total SIV DNA}

Viral RNA (vRNA) was isolated from plasma using a QIAamp viral RNA mini kit (Qiagen, Valencia, CA, United States). Total viral DNA (vDNA) was extracted from monkey peripheral blood mononuclear cells (PBMCs) using a QIAamp Blood DNA mini kit (Qiagen, Valencia, CA, United States) as previously reported (Chong et al., 2019). Viral RNA was subjected to quantitative real-time reverse transcription-PCR (qRT-PCR) on an ABI 9700 real-time PCR system (Applied Biosystems) using the following primers and probe: Gag91 forward primer: 5'-GCA GAG GAG GAA ATT ACC CAG TAC-3'; Gag91 reverse primer: 5'-CAA TTT TAC CCA GGC ATT TAA TGT T-3'; Probe: $5^{\prime}$-(FAM)ACC TGC CAT TAA GCC CGA-(MGB)-3'. The copy numbers were estimated by comparison to a pGEM-SIV gag477 standard

\section{A}
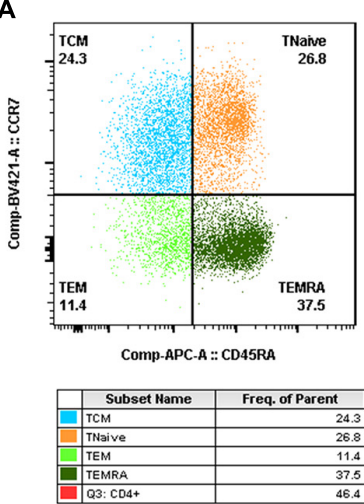

B

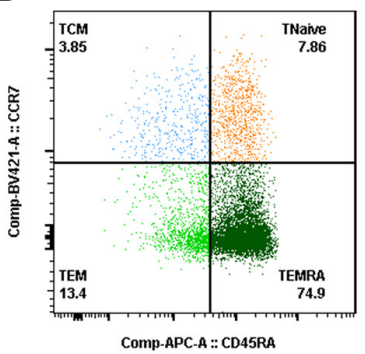

Comp-APC-A : CD45R

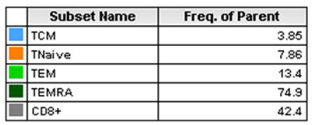

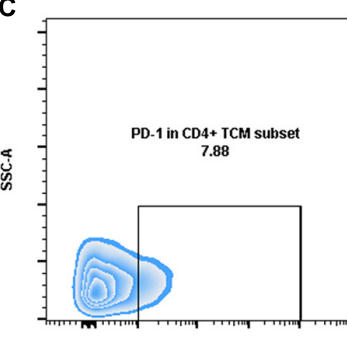

Comp-PerCP.Cy5-5-A :: PD-1

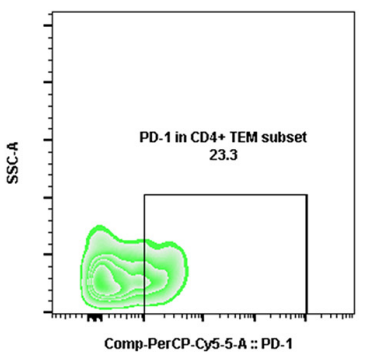

D
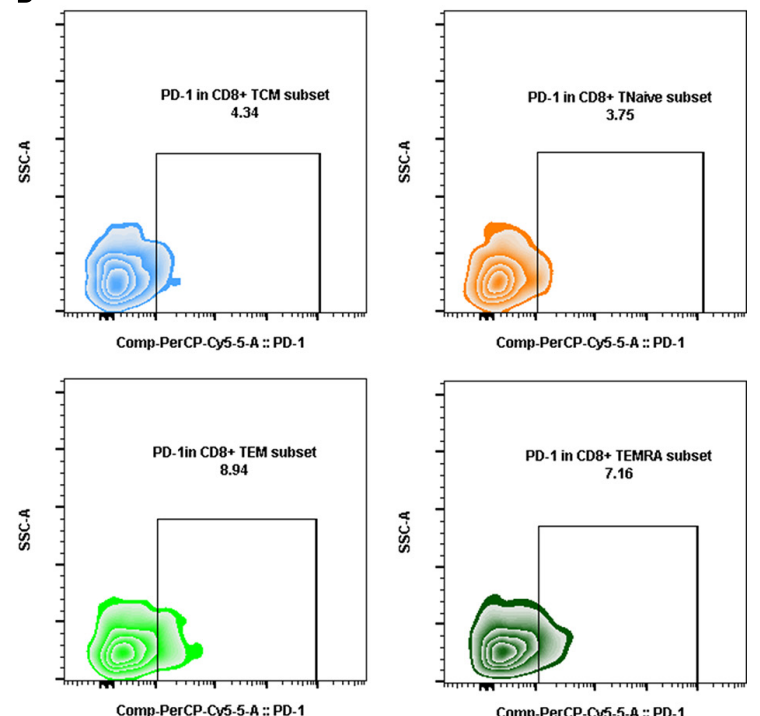

Comp-PerCP-Cy5-5.A:: PD-1

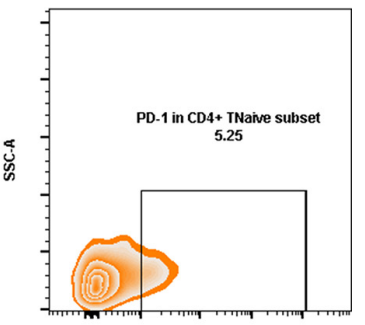

Comp-PerCP-Cy5.5-A:: PD-1

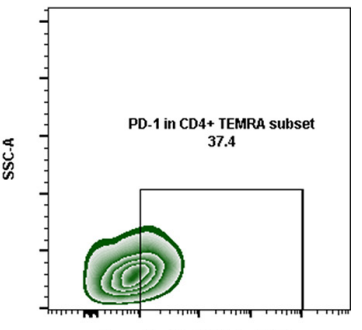

Comp-PerCP-Cy5-5-A :: PD-1

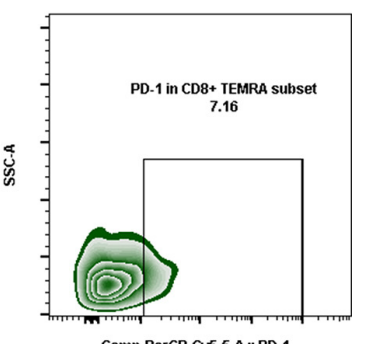

FIGURE 3 | Gating for memory T-cell subsets and PD-1+ cells in memory T-cell subsets by flow cytometry. (A,B) Gating for CD4 ${ }^{+}$memory T-cell subsets (A) and $\mathrm{CD}^{+}$memory T-cell subsets (B) with CCR7 and CD45RA expression $\left(\mathrm{T}_{\mathrm{CM}}, \mathrm{CD} 4^{+} / \mathrm{CD} 8^{+} \mathrm{CCR} 7^{+} \mathrm{CD} 45 \mathrm{RA}{ }^{-}\right.$, blue dot plot; $\mathrm{T}_{\mathrm{Naive}}, \mathrm{CD}^{+} / \mathrm{CD}^{+} \mathrm{CCR}^{+} \mathrm{CD} 45 \mathrm{RA}{ }^{+}$, orange dot plot; $\mathrm{T}_{\mathrm{EM}}, \mathrm{CD}^{+} / \mathrm{CD} 8^{+} \mathrm{CCR} 7^{-} \mathrm{CD} 45 \mathrm{RA}{ }^{-}$, light green dot plot; $\mathrm{TEMRA}_{\mathrm{E}}, \mathrm{CD} 4^{+} / \mathrm{CD} 8^{+} \mathrm{CCR} 7^{-} \mathrm{CD} 45 \mathrm{RA}{ }^{+}$, dark green dot plot). (C,D) Gating for PD-1+ cells in $\mathrm{CD} 4^{+}$memory T-cell subsets (C) and PD- $1^{+}$cells in $\mathrm{CD} 8^{+}$memory T-cell subsets (D) (PD-1+ $1_{\mathrm{CM}}, \mathrm{CD} 4^{+} / \mathrm{CD} 8^{+} \mathrm{PD}-1^{+} \mathrm{CCR} 7^{+} \mathrm{CD} 45 \mathrm{RA}{ }^{-}$, blue zebra plot;

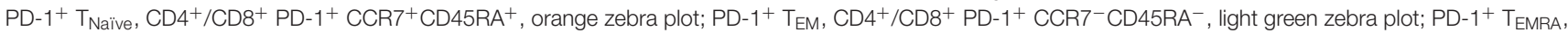
$\mathrm{CD}^{+} / \mathrm{CD}^{+} \mathrm{PD}-1^{+} \mathrm{CCR} 7^{-} \mathrm{CD} 45 \mathrm{RA}^{+}$, dark green zebra plot). 
curve. The limits of detection were 100 copy equivalents of RNA or DNA per $\mathrm{ml}$ of plasma. Triplicate test reactions were performed for each sample.

\section{Flow Cytometry}

Aliquots $(50 \mu \mathrm{l})$ of EDTA-treated whole blood were stained with monoclonal antibodies to CD3 PerCP (SP34-2, BD Biosciences, 552851), CD4 FITC (OKT-4, Biolegend, 317408), and CD8 PE (RPA-T8, BD Biosciences, 555367). CD4 ${ }^{+}$ T-cell counts were determined with $\mathrm{BD}$ Trucount tubes according to the manufacturer's instructions (BD Biosciences, San Diego, CA, United States). PBMCs were isolated using conventional Ficoll-Hypaque density gradient centrifugation (GE Healthcare, Uppsala, Sweden). Polychromatic flow cytometry was performed to quantitate activated $\mathrm{CD}^{+}$or $\mathrm{CD}^{+} \mathrm{T}$ lymphocytes (Figure 2) and $\mathrm{CD}^{+}$or $\mathrm{CD}^{+}$memory $\mathrm{T}$ lymphocyte subsets (Figure 3). Activated or memory $\mathrm{T}$ lymphocyte subsets (Table 1) from $1 \times 10^{6}$ PBMCs were stained with anti-CD3 BV605 (SP34-2, BD Biosciences, 562994), antiCD4 BV711 (OKT-4, Biolegend, 317440), anti-CD8 PE (RPA-T8, BD Biosciences, 557086), anti-CCR7 BV421 (G043H7, Biolegend, 352208), anti-CD45RA APC (5H9, BD Biosciences, 561210), anti-CD38 FITC (AT-1, Stemcell, 60131FI), anti-HLA-DR BV510 (G46-6, BD Biosciences, 563083), and anti-PD-1 PerCP-cy5.5 (EH12.2H7, Biolegend, 329914) monoclonal antibodies. Cells were resuspended in $1 \%$ paraformaldehyde, subjected to flow cytometry within $24 \mathrm{~h}$ on a FACSAriaII (BD Biosciences, San Diego, CA, United States), and analyzed using FlowJo $\mathrm{V}_{10}$ software.

\section{Multiplex Analysis Using Luminex}

Blood samples were centrifuged for $10 \mathrm{~min}$ at $600 \times \mathrm{g}$, and serum was immediately aliquoted and stored at $-80^{\circ} \mathrm{C}$. The following 11 cytokines were measured with a Luminex kit following the manufacturer's instructions: IL-1 $\beta$, IL-2, IL-6, IL8, IL-10, IFN- $\gamma$, MCP-1, MIP-1 $\beta$, TNF- $\alpha$ (Merck Millipore, Billerica, MA, United States, PRCYTOMAG-40K-09C), TGF- $\beta$ (Merck Millipore, Billerica, MA, United States, TGFBMAG-64K01), and IP-10 (Carlsbad, CA, United States, EPX01A-40284901). After thawing the samples on ice and sufficient mixing, $25 \mu \mathrm{l}$ of supernatant was loaded into each well of a 96-well plate and mixed with $25 \mu \mathrm{l}$ of assay buffer and $25 \mu \mathrm{l}$ of magnetic beads. The plates were incubated with agitation overnight at $4^{\circ} \mathrm{C}$. After washing, $25 \mu \mathrm{l}$ of detection antibody was added to each well, and the plate was incubated for $1 \mathrm{~h}$ at room temperature (RT). Then, $25 \mu \mathrm{l}$ of streptavidin-PE was added to each well and incubated for $30 \mathrm{~min}$ at RT. Next, $150 \mu \mathrm{l}$ sheath fluid was added to each well after washing. Plates were read on a Luminex ${ }^{\circledR} 200$ (BioRad, Hercules, CA, United States), and the data were analyzed for median fluorescent intensity using a five-parameter logistic method for calculating analyte concentration.

\section{Statistical Analysis}

Comparisons between the two groups were determined using paired $t$-tests. Comparison of quantitative variables was assessed with Friedman's test. The Spearman rank test was used to determine correlations. All data were analyzed using GraphPad
Prism 9.0 software (GraphPad Software Inc., San Diego, CA, United States). Significance was set at ${ }^{*} P<0.05$, ${ }^{* *} P<0.01$, and $* * * P<0.001$.

\section{RESULTS}

\section{Generation of the ART-Treated, SIVmac239-Infected Monkey Model}

Eight rhesus monkeys were intravenously infected with 100 TCID $_{50}$ SIVmac239. A 3-month ART regimen consisting of daily s.c. injections of TDF, DTG, and FTC was continued from 98 days post-infection (dpi), with a 49-day follow-up after stopping ART. During the observation periods, the levels of viral RNA and total viral DNA were measured, together with counts of $\mathrm{CD}^{+}$ $\mathrm{T}$ cells and ratios of immunocyte subsets and quantification of cytokine levels (Figure 1). Data collection for the model was divided into four stages: baseline (pre-infection), infection, treatment, and withdrawal based on the variation of vRNA replication (Figure 4A). Regarding the virus, at the baseline stage, SIV was negative (SN, "baseline"); after acute and chronic SIV infection, SIV emerged (SE, "infection") with a peak plasma SIV RNA level of $6.91 \log _{10}$ copies/ml (range 5.75-7.58 $\log _{10}$ RNA copies/ml); during ART, the SIV replication was suppressed (SS, "treatment") to undetectable levels (limits of detection, $2.00 \log _{10}$ RNA copies/ml); after cessation of ART, the SIV RNA rebounded (SR, "withdrawal") with the peak of plasma viral RNA ranging from 4.60 to $6.99 \log _{10}$ RNA copies/ml. The longitudinal vDNA ranged from 3.20 to $3.90 \log _{10} \mathrm{vDNA}$ copies/ml after acute SIV infection. The vDNA in the SR phase was significantly lower than in the SE phase (SR vs. SE, $P=0.0009$ ) (Figure $4 \mathbf{B}$, right panel).

The CD $4^{+}$T-cell counts and CD4/CD8 ratios were compared to determine the status of immune reconstitution. $\mathrm{CD}^{+}{ }^{+} \mathrm{T}$-cell counts during ART (SS phase) were slightly increased, but differences were not significant (SS vs. SE, $P=0.4044$; and SS vs. SR, $P=0.8061$ ) (Figure $4 \mathrm{C}$ ). CD4/CD8 ratios in the SS phase were significantly increased compared with those during SE (SS vs. SE, $P=0.0017$ ) and in the SR phase (SS vs. SR, $P=0.0128$ ),

TABLE 1 | Polychromatic flow cytometry for staining of T lymphocyte subsets.

\begin{tabular}{|c|c|}
\hline T lymphocyte subsets & Biomarker \\
\hline \multirow[t]{4}{*}{ Activated $T$ cells } & $\mathrm{CD}^{+} / \mathrm{CD}^{+} \mathrm{CD}^{+} 8^{+} \mathrm{HLA}^{-\mathrm{DR}^{+}}$ \\
\hline & $\mathrm{CD}^{+} / \mathrm{CD}^{+} \mathrm{CD}^{+} 8^{+} \mathrm{HLA}^{-\mathrm{DR}^{-}}$ \\
\hline & $\mathrm{CD}^{+} / \mathrm{CD}^{+} \mathrm{CD}^{-} 8^{-} \mathrm{HLA}^{-\mathrm{DR}^{+}}$ \\
\hline & $\mathrm{CD}^{+} / \mathrm{CD}^{+} \mathrm{CD}^{-} 8^{-} \mathrm{HLA}^{-\mathrm{DR}^{-}}$ \\
\hline Naive $T$ cells ( $\left.T_{\text {Naive }}\right)$ & $\mathrm{CD}^{+} \mathrm{CD}^{+} / \mathrm{CD}^{+} \mathrm{CCR}^{+} \mathrm{CD}^{+} 5 \mathrm{RA}^{+}$ \\
\hline $\mathrm{PD}-1^{+} \mathrm{T}_{\text {Naive }}$ & $\mathrm{CD}^{+} \mathrm{CD}^{+} / \mathrm{CD}^{+} \mathrm{CCR}^{+} \mathrm{CD}^{+} 5 \mathrm{RA}{ }^{+} \mathrm{PD}-1^{+}$ \\
\hline Central memory $\mathrm{T}$ cells $\left(\mathrm{T}_{\mathrm{CM}}\right)$ & $\mathrm{CD}^{+} \mathrm{CD}^{+} / \mathrm{CD}^{+}{ }^{+} \mathrm{CCR} 7^{+} \mathrm{CD}_{45 \mathrm{RA}^{-}}$ \\
\hline $\mathrm{PD}-1^{+} \mathrm{T}_{\mathrm{CM}}$ & $\mathrm{CD}^{+} \mathrm{CD}^{+} / \mathrm{CD}^{+} \mathrm{CCR}^{+} \mathrm{CD}^{+} 5 \mathrm{RA}^{-} \mathrm{PD}-1^{+}$ \\
\hline $\begin{array}{l}\text { Effector memory } \mathrm{RA}^{+} \mathrm{T} \text { cells } \\
\left(\mathrm{T}_{\text {EMRA }}\right)\end{array}$ & $\mathrm{CD}^{+} \mathrm{CD}^{+} / \mathrm{CD}^{+}{ }^{+} \mathrm{CCR}^{-}{ }^{-} \mathrm{CD}_{45 \mathrm{RA}^{+}}$ \\
\hline $\mathrm{PD}-1^{+} \mathrm{T}_{\text {EMRA }}$ & $\mathrm{CD}^{+} \mathrm{CD}^{+} / \mathrm{CD}^{+} \mathrm{CCR}^{-} \mathrm{CD}^{-} 5 \mathrm{RA}^{+} \mathrm{PD}-1^{+}$ \\
\hline Effective memory $T$ cells ( $\left.T_{E M}\right)$ & $\mathrm{CD}^{+} \mathrm{CD}^{+} / \mathrm{CD}^{+} \mathrm{CCR}^{-} \mathrm{CD}^{-} 5 \mathrm{RA}^{-}$ \\
\hline $\mathrm{PD}-1+\mathrm{T}_{\mathrm{EM}}$ & $\mathrm{CD}^{+}{ }^{+} \mathrm{CD} 4^{+} / \mathrm{CD}^{+}{ }^{+} \mathrm{CCR} 7^{-} \mathrm{CD} 45 \mathrm{RA}^{-} \mathrm{PD}-1^{+}$ \\
\hline
\end{tabular}




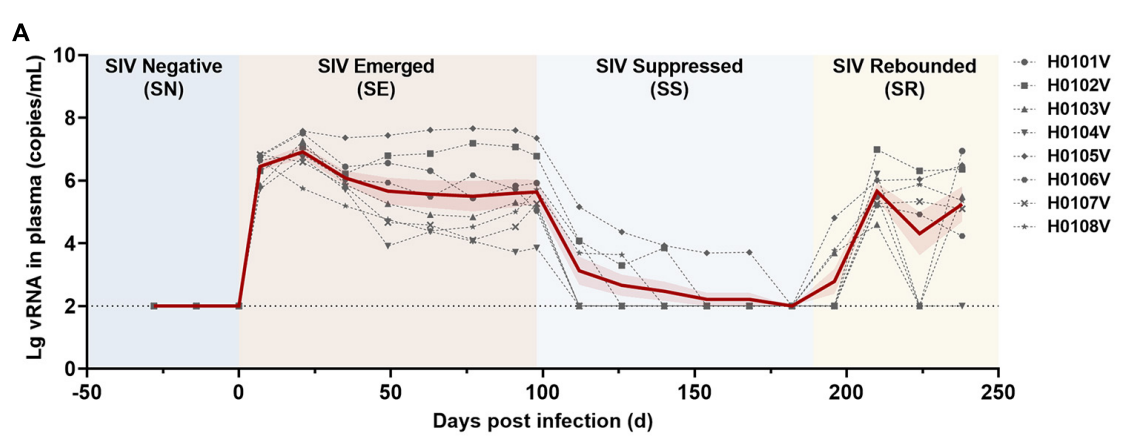

B

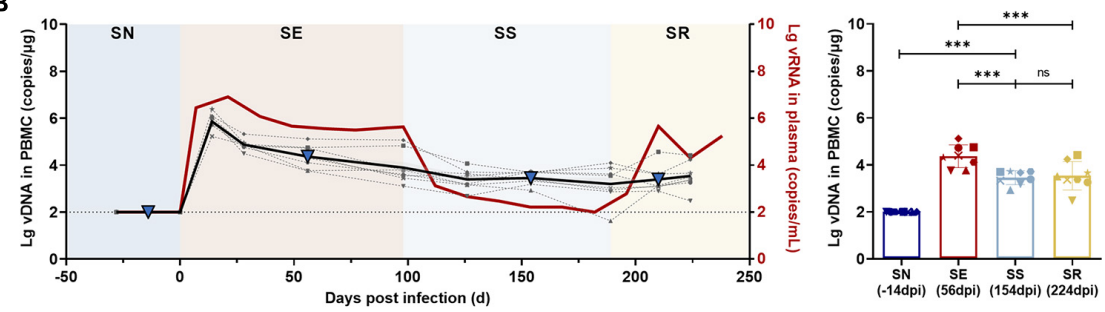

C

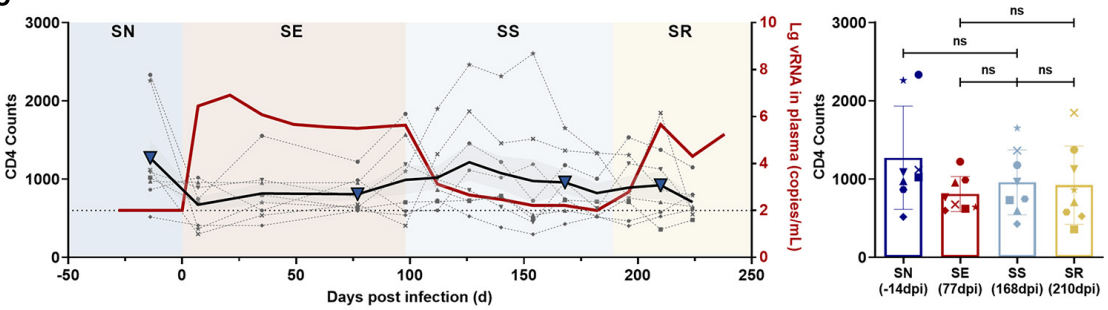

D

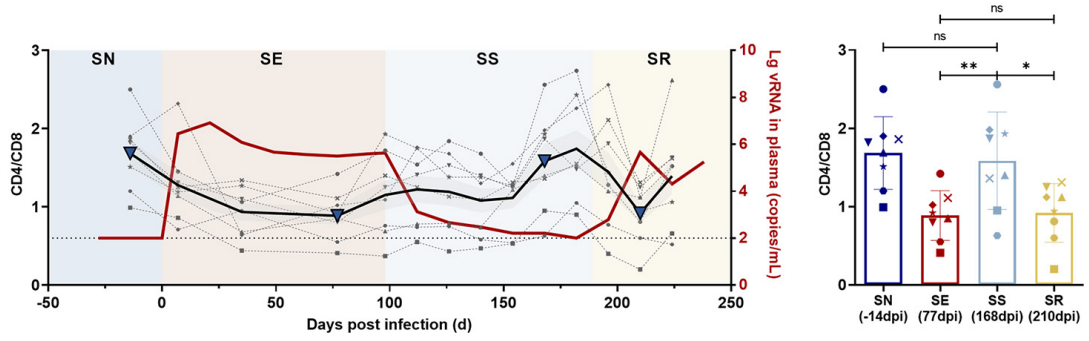

FIGURE 4 | Dynamics of viral RNA, viral DNA, CD4 T-cell counts, and CD4/CD8 ratio in ART-treated, SIVmac239-infected macaques. (A) Dynamics of viral RNA replication. The observation period was divided into four phases according to viral replication: SIV negative (SN), SIV emerged (SE), SIV suppressed (SS), and SIV rebounded (SR). The gray dotted lines indicate the changes in viral RNA in each monkey; the solid red line, the average of viral loads for all monkeys; the red shaded area, the SEM of viral loads for all monkeys. (B-D) Dynamics of total viral DNA, CD4 T-cell counts, and CD4/CD8 ratio during the observation period. Left panel, the changes in (B) total viral DNA, (C) CD4 T-cell counts, and (D) CD4/CD8 ratio during the four phases (gray dotted line, changes in each monkey; black solid line, the average of all monkeys; gray shaded areas, the SD of all monkeys; solid red line, the average viral loads of all monkeys). Right panel, comparisons among SN, SE, SS, and SR. The blue triangles in the left panel represent the time points in the right panel. $\left({ }^{\star} P<0.05,{ }^{\star \star} P<0.01,{ }^{\star \star \star} P<0.001\right.$, paired $t$-test).

which returned to the normal level before infection (SS vs. SN, $P=0.4280$ ) (Figure 4D).

\section{Significant Increase in Activated or PD-1-Expressing T Cells With Elevated Levels of Inflammatory Cytokines in SS vs. SN}

Ratios of $\mathrm{CD}^{+} 8^{+} \mathrm{HLA}^{-D R^{-}} \mathrm{CD}^{+} \quad(P=0.0027) / \mathrm{CD} 8^{+}$ $(P=0.0373)$ T-cell subsets in the SS phase were significantly higher than in $\mathrm{SN}$ before infection (Figures $5 \mathrm{~A}, \mathrm{E}$ ). No

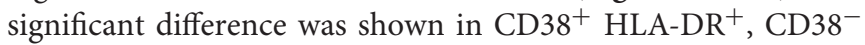
$\mathrm{HLA}^{-\mathrm{DR}^{+}}$, or $\mathrm{CD}^{-} 8^{-} \mathrm{HLA}^{-\mathrm{DR}^{-}}$activated $\mathrm{CD} 4^{+} / \mathrm{CD} 8^{+}$
T-cell subsets between SS and SN phases $(P>0.05)$. For memory $\mathrm{CD}^{+} / \mathrm{CD}^{+}$T-cell subsets, $\mathrm{CD} 4^{+} / \mathrm{CD} 8^{+} \mathrm{T}_{\mathrm{CM}}$, $\mathrm{T}_{\text {Naive }}, \mathrm{T}_{\mathrm{EMRA}}$, or $\mathrm{T}_{\mathrm{EM}}$ during ART (SS) were not significantly different compared to those in SN (Figure 5B). There was a significant increase in $\mathrm{PD}$-1-expressing $\mathrm{T}$-cell subsets during SS including $\mathrm{PD}-1^{+} / \mathrm{CD} 4^{+} \mathrm{T}_{\mathrm{CM}}(P=0.0018)$ and $\mathrm{PD}-1^{+} / \mathrm{CD} 4^{+} \mathrm{T}_{\mathrm{EM}}(P=0.0165)$ (Figure $5 \mathrm{C}$, left panel and Figure 5E) as well as $\mathrm{PD}-1^{+} / \mathrm{CD} 8^{+} \mathrm{T}_{\mathrm{CM}}(P=0.0270)$ and $\mathrm{PD}-1^{+} / \mathrm{CD}^{+} \mathrm{T}_{\mathrm{EM}}(P=0.0106)$ (Figure $5 \mathrm{C}$, right panel and Figure 5E) compared to before infection. Serum profiles of anti- and pro-inflammatory cytokines and chemokines were compared between SS and SN (Figure 6). IL-10 $(P=0.0482)$, IL-8 $(P=0.0040)$, and MIP-1 $\beta$ 
$(P=0.0080)$ were significantly elevated in SS compared to SN phase (Figures 5D,E).

\section{Significant Shift in PD-1-Activated T Cells With Elevated Inflammatory Cytokines in Relation to SIV Replication \\ in SR vs. SE}

Comparing SR to SE, we found no significant difference in activated $\mathrm{CD} 4^{+} / \mathrm{CD}^{+}{ }^{+} \mathrm{T}$-cell subsets with $\mathrm{CD} 38$ and/or HLA-DR expression (Figure 7A) as well as memory T-cell subsets with CCR7 and/or CD45RA expression (Figure 7B) $(P>0.05)$. The only significant changes were an increase in $\mathrm{PD}-1^{+} \mathrm{CD} 4^{+} \mathrm{T}_{\mathrm{CM}}$ cells $(p=0.0110)$ and decrease in $\mathrm{PD}-1^{+} \mathrm{CD} 4^{+} \mathrm{T}_{\mathrm{EM}}$ cells $(P=0.0466)$ in SR compared to SE (Figure 7C, left panel and Figure $7 \mathrm{E})$. IFN- $\gamma(P=0.0234), \mathrm{IL}-1 \beta(P=0.0169)$, IL-6 $(P=0.0164)$, and TNF- $\alpha(P=0.0435)$ were significantly elevated in SR compared to SE (Figures 7D,E).

\section{Systematic Comparison of the Level of Inflammation in ART-Treated SIVmac239-Infected Rhesus Macaques}

Percentages of specific immune cells and cytokine levels in the four phases of "baseline-infection-treatment-withdrawal" were systematically compared in SN vs. SS and SE vs.
A

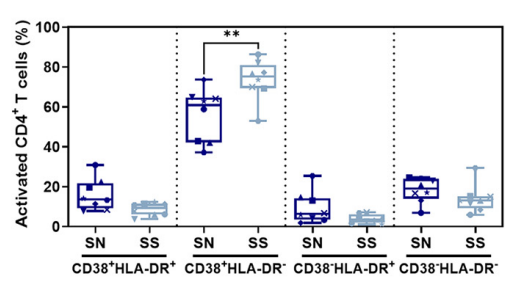

B

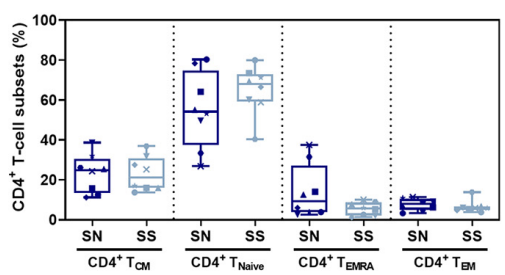

C
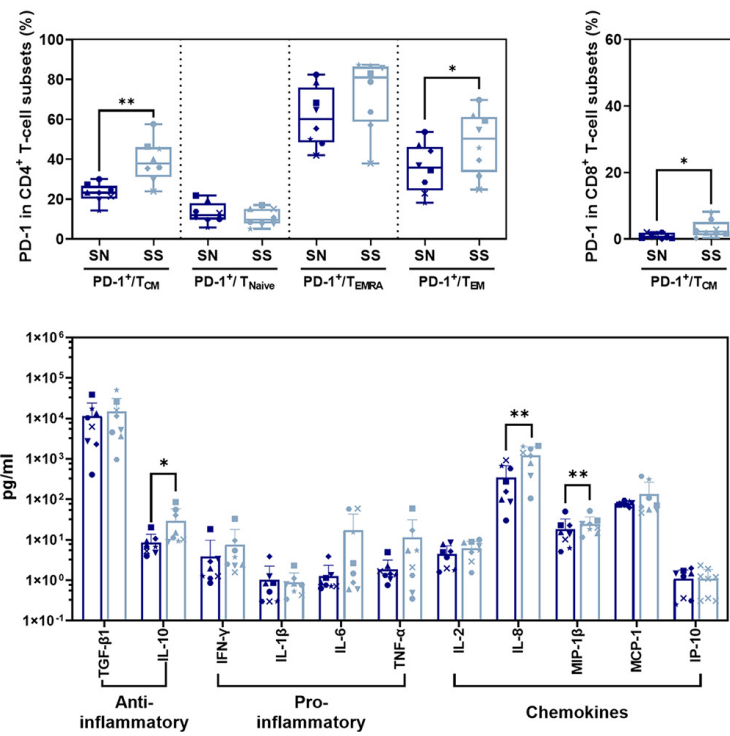
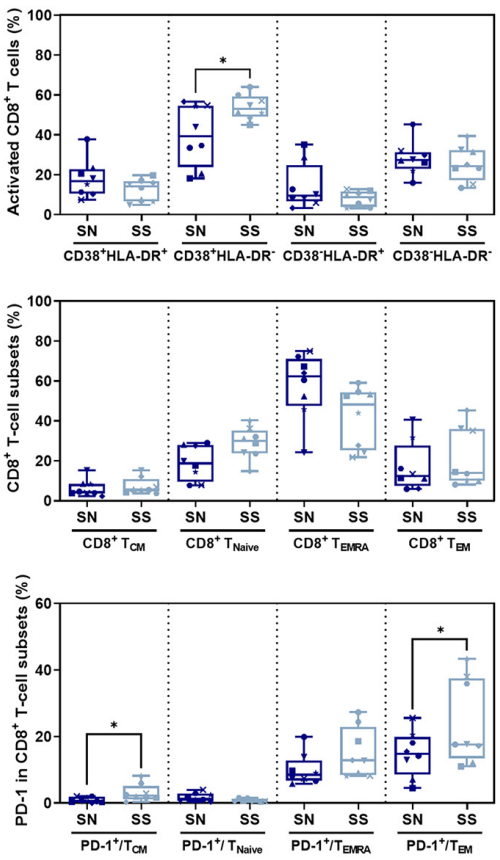

E

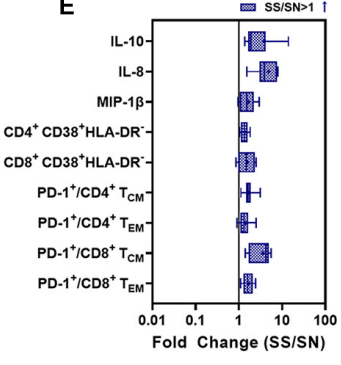

FIGURE 5 | Comparison of CD4+/CD8 ${ }^{+}$T-cell subsets and cytokines between SS and SN phases. (A) Comparison of activated CD4+ (left panel) and CD8 ${ }^{+}$(right panel) T-cell subsets from PBMC in SS vs. SN. (B) Comparison of CD4+ (left panel) and CD8 ${ }^{+}$(right panel) memory T-cell subsets from PBMC in SS vs. SN. The

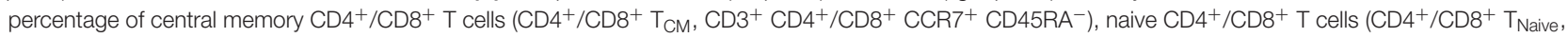
$\left.\mathrm{CD}^{+} \mathrm{CD}^{+} / \mathrm{CD}^{+} \mathrm{CCR}^{+} \mathrm{CD}^{2} 5 \mathrm{RA}^{+}\right)$, TEMRA cells $\left(\mathrm{CD} 4^{+} / \mathrm{CD} 8^{+} \mathrm{T}_{\mathrm{EMRA}}, \mathrm{CD}^{+} \mathrm{CD} 4^{+} / \mathrm{CD}^{+}{ }^{+} \mathrm{CCR} 7^{-} \mathrm{CD} 45 \mathrm{RA}^{+}\right)$, and effective memory $\mathrm{T}$ cells $\left(\mathrm{CD} 4^{+} / \mathrm{CD} 8^{+}\right.$ $\mathrm{T}_{\mathrm{EM}}, \mathrm{CD}^{+} \mathrm{CD}^{+} / \mathrm{CD} 8^{+} \mathrm{CCR} 7^{-} \mathrm{CD} \mathrm{SRA}{ }^{-}$) were compared between SS and SN phases (paired $t$-test, $P>0.05$ ). (C) Comparison of percentages of PD-1+ cells in memory T-cell subsets in SS vs. SN. Left panel, comparison of percentages of PD-1 $1^{+}$cells in CD4 ${ }^{+} \mathrm{T}_{\mathrm{CM}}, \mathrm{T}_{\mathrm{Naive}}, \mathrm{T}_{\mathrm{EMRA}}$, and $\mathrm{T}_{\mathrm{EM}}$ cells; right panel, comparison of percentages of PD-1+ cells in CD8 ${ }^{+} \mathrm{T}_{\mathrm{CM}}, \mathrm{T}_{\text {Naive, }}, \mathrm{T}_{\mathrm{EMRA}}$, and $\mathrm{T}_{\mathrm{EM}}$ cells. (D) Comparison of anti- and pro-inflammatory cytokines and chemokines between SS and SN phases. (E) Fold change of cytokines and T-cell subsets with significant differences (SS value/SN value; blue filled patterns represent increased values). Data are the mean $\pm \mathrm{SD}$ from three independent experiments $\left(* P<0.05,{ }^{*} P<0.01\right.$, paired $t$-test, $S S$ vs. SN). 
SR (Figure 8A). The frequency of immunocyte types and cytokine expression levels were compared among the four stages (Figure 8B). Activated $\mathrm{CD} 4^{+}$T-cell subsets with high expression of CD38 or HLA-DR and memory $\mathrm{CD} 4^{+} / \mathrm{CD} 8^{+} \mathrm{T}$-cell subsets with high expression of $\mathrm{PD}-1$ were consistently sustained from stage to stage.
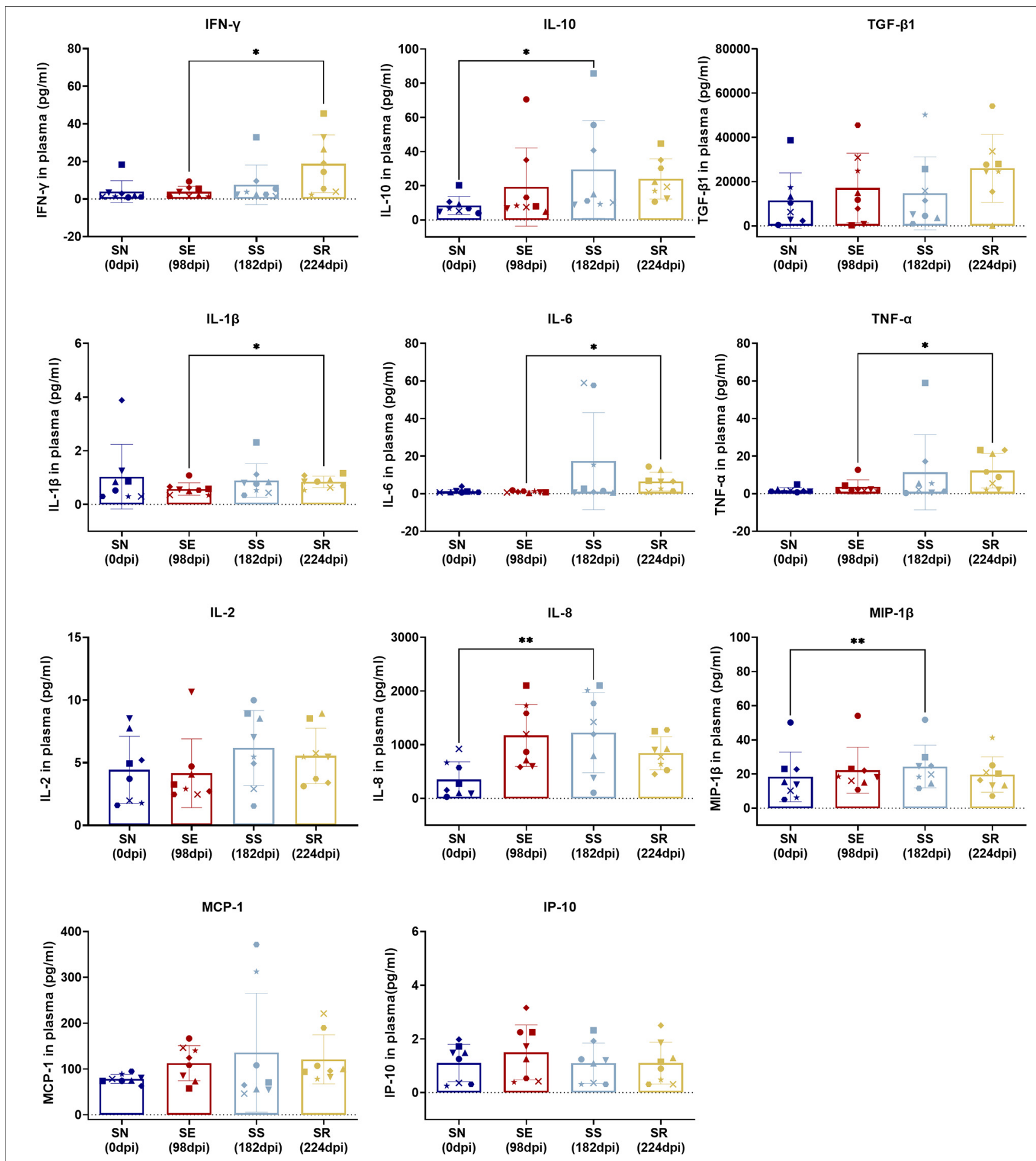

FIGURE 6 | Comparison of cytokines between SS and SN and between SR and SE. Cytokines were detected in the serum of SIV-infected macaques at the indicated phase. Levels (pg/ml) of IFN- $\gamma$, IL-10, TGF- $\beta 1$, IL-1 $\beta, \mathrm{IL}-6$, TNF- $\alpha, \mathrm{IL}-2, \mathrm{IL}-8, \mathrm{MIP}-1 \beta$, MCP-1, and IP-10 were measured and assessed by paired $t$-test in SS vs. SN and SR vs. SE. Data shown are the mean \pm SD from three independent experiments $\left({ }^{*} P<0.05,{ }^{* *} P<0.01\right)$. 
A

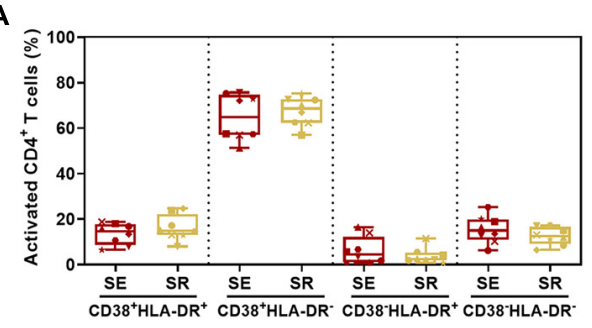

B

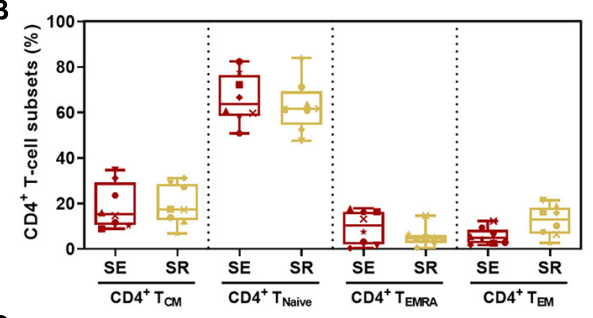

C

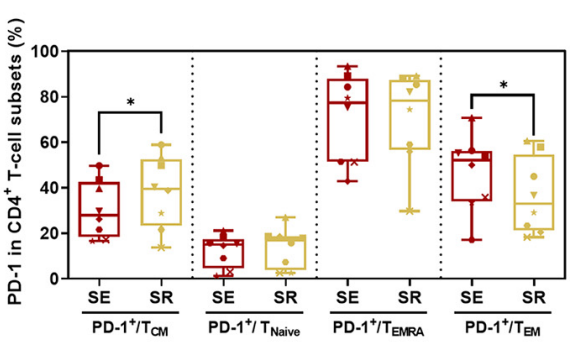

D

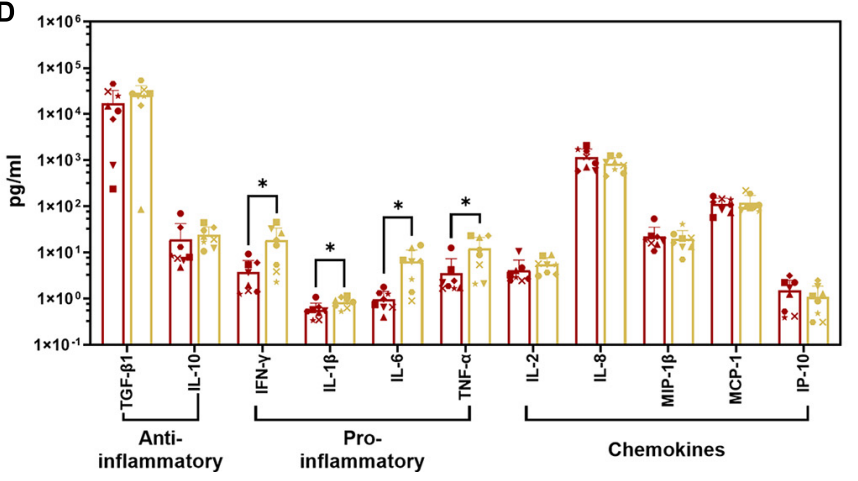

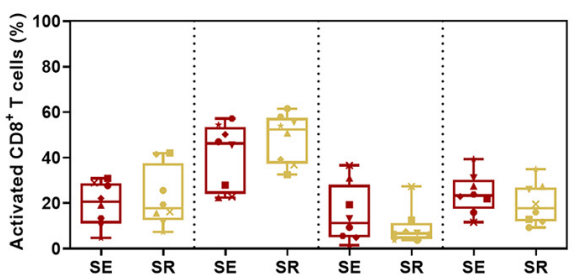

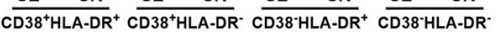
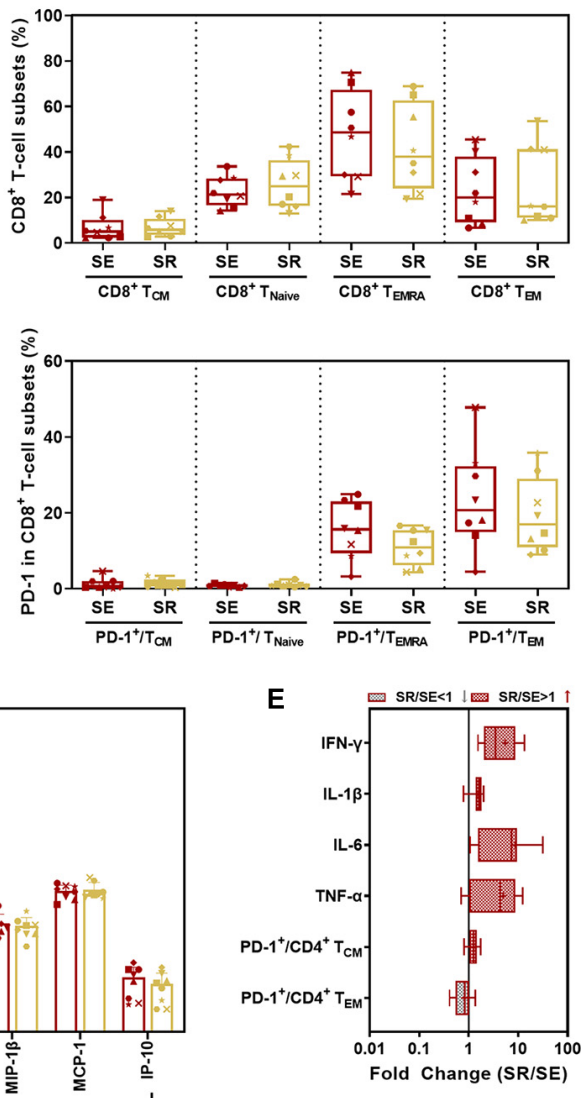

FIGURE 7 | Comparison of $\mathrm{CD}^{+} / \mathrm{CD} 8^{+}$T-cell subsets and cytokines between SR and SE phases. (A) Comparison of activated CD4 ${ }^{+}\left(\right.$left panel) and CD8 $8^{+}$(right panel) T-cell subsets from PBMC in SR vs. SE. (B) Comparison of CD4+ (left panel) and CD8 (right panel) memory T-cell subsets from PBMCs in SR vs. SE. The percentage of central memory $\mathrm{CD} 4^{+} / \mathrm{CD} 8^{+} \mathrm{T}$ cells $\left(\mathrm{CD} 4^{+} / \mathrm{CD} 8^{+} \mathrm{T}_{\mathrm{CM}}, \mathrm{CD}^{+} \mathrm{CD} 4^{+} / \mathrm{CD} 8^{+} \mathrm{CCR} 7^{+} \mathrm{CD} 45 \mathrm{RA}^{-}\right)$, naive $\mathrm{CD}^{+} / \mathrm{CD}^{+} \mathrm{T}_{\text {cells }}\left(\mathrm{CD} 4^{+} / \mathrm{CD} 8^{+} \mathrm{T}_{\mathrm{Naive}}\right.$,

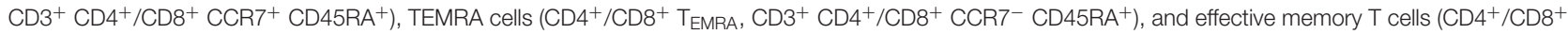
$\mathrm{T}_{\mathrm{EM}}, \mathrm{CD}^{+} \mathrm{CD}^{+} / \mathrm{CD}^{+}{ }^{+} \mathrm{CCR} 7^{-} \mathrm{CD} 45 \mathrm{RA}{ }^{-}$) were compared between SR and SE phases (paired $t$-test, $P>0.05$ ). (C) Comparison of percentages of PD- $1^{+}$cells in memory T-cell subsets in SR vs. SE. Left panel, comparison of percentages of PD-1+ cells in CD4 ${ }^{+} \mathrm{T}_{\mathrm{CM}}, \mathrm{T}_{\mathrm{Naive}}, \mathrm{T}_{\mathrm{EMRA}}$, and $\mathrm{T}_{\mathrm{EM}}$ cells; right panel, comparison of percentages of PD- $1^{+}$cells in $C D 8^{+} \mathrm{T}_{\mathrm{CM}}, \mathrm{T}_{\text {Naive }}, \mathrm{T}_{\mathrm{EMRA}}$, and $\mathrm{T}_{\mathrm{EM}}$ cells. (D) Comparison of anti- or pro-inflammatory cytokines and chemokines between SR and SE phases. (E) The fold change of cytokines and T-cell subsets with the significant differences (SR value/SE value; red-filled patterns are the increased values, and gray-filled patterns are the decreased values). Data are mean $\pm \mathrm{SD}$ from three independent experiments $\left({ }^{*} P<0.05\right.$, paired $t$-test, SR vs. SE).

\section{DISCUSSION}

Our comparison was based on longitudinal within-individual analyses of host-virus interaction on $\mathrm{CD} 4^{+} \mathrm{T}$ cells (supposed target) and $\mathrm{CD}^{+} \mathrm{T}$ cells (supposed effector). We systematically measured the subset of activation status in conjunction with their exhaustion status and cytokine profiling in non-human primate models. Our stage-dependent host-virus immunity comparison longitudinally tracked eight SIVmac239-infected rhesus macaques. We stratified the SIV persistent scenario by viral load representative of viral stimulation (acute) or persistence (chronic/latent) to obtain four individual-based stages. We compared SS to SN to reveal the host-virus interaction in the context of virus-undetectable host immunity status. Also, we compared SR to SE to reveal the host-virus interaction in the context of virus-detectable host immunity status. In each single 
stage, our findings were highly consistent with previous studies (Hunt et al., 2008; Molina-Pinelo et al., 2009; Robbins et al., 2009; Hunt, 2012; Vandergeeten et al., 2012; Wittkop et al., 2013; Osuji et al., 2018; Yero et al., 2019; Antar et al., 2020; Bordoni et al., 2020).

Comparing SS and SN, we found significantly elevated CD38 ${ }^{+}$ activated $\mathrm{CD}^{+} / \mathrm{CD}^{+}$T-cell subsets and $\mathrm{PD}-1^{+}$memory $\mathrm{CD}^{+} / \mathrm{CD}^{+}{ }^{+} \mathrm{T}$-cell subsets. T-cell activation by elevated CD38 and HLA-DR co-expression during HIV acute infection is commonly seen (Hua et al., 2014; Ndhlovu et al., 2015; Chen et al., 2017). It was worthy to note that CD38 expression indicated the activation against HIV and displays a tendency to exhaustion. HLA-DR was observed at the earlier phase of the acute infection and waned during the long-term SS stage. Therefore, the difference between SN and SS presented a $\mathrm{CD}^{+}{ }^{+} \mathrm{HLA}^{-D R}{ }^{-}$subset. Furthermore, overexpressed PD-1 was shown between two stages. It has been documented that high expression of PD-1 and CD38 on CD8 ${ }^{+} \mathrm{T}$ cells is correlated with viral replication and disease progression in long-term chronic cases, indicating exhaustion of activated T cells (Hoffmann et al., 2016). Also, memory $\mathrm{CD}^{+} \mathrm{T}$ cells are continuously exhausted with overexpression of PD-1 (Evans et al., 2018). Collectively, our between-stage (SS vs. SN) comparison validated a dynamic process of activation/exhaustion during chronic latency along individual scenarios. Notably, such activation/exhaustion might produce "paradoxical" cytokines. Our comparison revealed MIP$1 \beta$, IL-8, and IL-10 as the most prominent. As ART suppresses dominant cytokines cascade into low levels (Hansen et al., 2009; Casetti et al., 2017; Sereti et al., 2017; Bordoni et al., 2020), pro-inflammatory MIP- $1 \beta$ and IL- 8 and anti-inflammatory factor IL-10 are secreted to exaggerate the imbalance of host immunity. Also, such imbalance of cytokine microenvironment is likely to promote $\mathrm{CD}^{+} \mathrm{T}$ cells' susceptibility to senescence/apoptosis, forming a chronic vicious circle. Therefore, our stage-dependent comparison validated the "paradoxical" activation/exhaustion of HIV/SIV-specific memory/effector T cells, which responded to the latent and continuous HIV/SIV antigen representation.

Comparing SR and SE, we found increased $\mathrm{PD}-1^{+} \mathrm{CD} 4^{+}$ $\mathrm{T}_{\mathrm{CM}}$ cells with decreased $\mathrm{PD}-1^{+} \mathrm{CD} 4^{+} \mathrm{T}_{\mathrm{EM}}$ cells and four remarkedly increased pro-inflammatory cytokines. These results suggested that the targeted $\mathrm{CD}^{+} \mathrm{T}$ cells were undergoing exhaustion and senescence. During HIV replication, $\mathrm{CD}^{+}{ }^{+} \mathrm{T}$ cells were impaired, resulting in reduced immunity hemostasis. In previous studies, the majority of $\mathrm{PD}-1$ is overexpressed

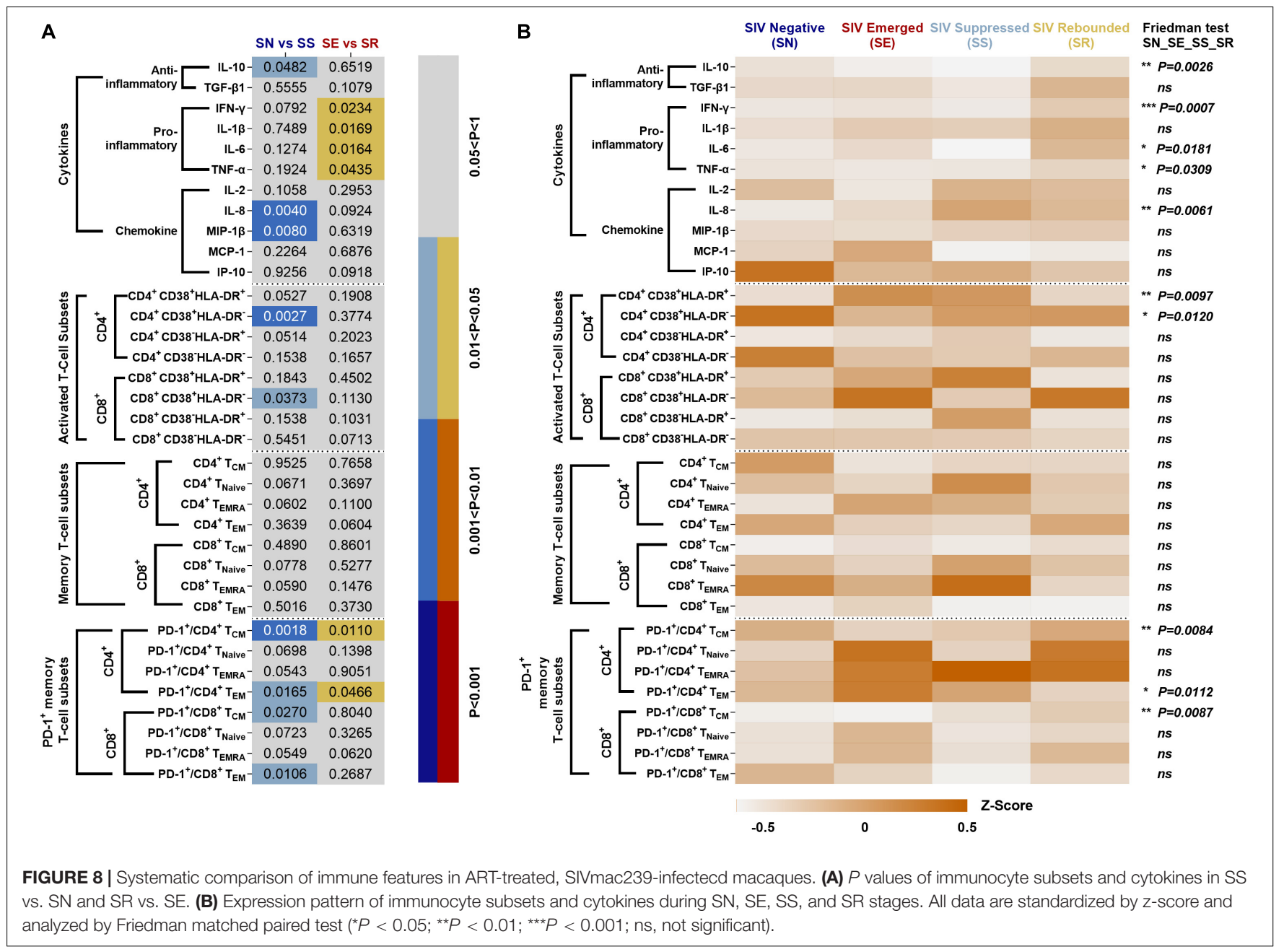


on the memory $\mathrm{CD}^{+} \mathrm{T}$ cells in both $\mathrm{SR}$ and $\mathrm{SE}$ stages (Hansen et al., 2009), which could explain the low disparity between the two stages. Regarding the cytokines, non-specific and robust pro-inflammatory cytokines including TNF- $\alpha$, IL-6, and IFN- $\gamma$ (Regidor et al., 2011; Vandergeeten et al., 2012; Osuji et al., 2018) were significantly elevated. Such pro-inflammatory profiling indicated that the host immunity was hyperactive and imbalanced. It was paradoxical that such robust cytokines could not eliminate the rebounding virus, which was also attributed to the imbalanced cytokine shift. As the SR stage occurred after a long host-virus interaction undergone ART treatment, it meant that host global immunocompetence was eventually shifted from activation/exhaustion to exhaustion/senescence, reflected by our differential cytokine profiling between the two stages (SE vs. SR).

Our study had numerous limitations. First, the size of our non-primate monkeys was relatively small, leading to the low validity of the present findings. Secondly, we merely measured PD-1 among a bundle of checkpoint receptors, such as Tim-3 and Lag-3, to represent immune checkpoint receptors on CD4 and $\mathrm{CD}^{+} \mathrm{T}$ cells. Thirdly, the profound polyfunctionality of $\mathrm{CD}^{+}$and $\mathrm{CD}^{+}{ }^{+} \mathrm{T}$ cells and cytokine profiles have not been comprehensively measured. Fourthly, the dynamic trajectory on $\mathrm{CD}^{+}{ }^{+}$and $\mathrm{CD}^{+}$T-cell functionality and cytokine profiles was not individually tracked and explained by intra-individual and inter-individual variation due to the small size and low frequency of measurements. Fifthly, the co-expression was not joint analyzed as most combinations of multiple phenotypes were functionally undetermined.

In summary, our stage-dependent individual-traced comparison has presented an eventual shifting tendency from activation/exhaustion to exhaustion/senescence using eight rhesus macaques undergoing four stages. It was supposed that sustained expression of PD-1 attempted to check the point and maintain the balance, yet actually accelerated the immune activation and exhausted the immunity response. The dynamic imbalance and shift of host immunity during the chronic scenario could be individually seen using the present within-individual comparison. Overall, this stage-dependent longitudinal comparison further confirmed that SIV accelerates host immunosenescence continuously independent of viral replication, the findings of which may provide insights into identifying targets for novel intervention reducing persistent immunoactivation in ART-treated individuals.

\section{REFERENCES}

Antar, A. A., Jenike, K. M., Jang, S., Rigau, D. N., Reeves, D. B., Hoh, R., et al. (2020). Longitudinal study reveals HIV-1-infected CD4+ T cell dynamics during longterm antiretroviral therapy. J. Clin. Invest. 130, 3543-3559. doi: 10.1172/ jci135953

Appay, V., Almeida, J. R., Sauce, D., Autran, B., and Papagno, L. (2007). Accelerated immune senescence and HIV-1 infection. Exp. Gerontol. 42, 432-437. doi: 10.1016/j.exger.2006.12.003

Appay, V., and Sauce, D. (2017). Assessing immune aging in HIV-infected patients. Virulence 8, 529-538. doi: 10.1080/21505594.2016.1195536

Booiman, T., Wit, F. W., Girigorie, A. F., Maurer, I., De Francesco, D., Sabin, C. A., et al. (2017). Terminal differentiation of $\mathrm{T}$ cells is strongly associated with

\section{DATA AVAILABILITY STATEMENT}

The original contributions presented in the study are included in the article/supplementary material, further inquiries can be directed to the corresponding authors.

\section{ETHICS STATEMENT}

The animal study was reviewed and approved by Institutional Animal Care and Use Committee (IACUC) of the Institute of Laboratory Animal Science, Chinese Academy of Medical Sciences.

\section{AUTHOR CONTRIBUTIONS}

JX: conceptualization and writing-review and editing. ZC and LTo: methodology. LTo, ZC, LTi, JZ, JL, QL, and TC: investigation. LTo and YW: statistical analysis. LTo and JX: writing-original draft. JX, QW, and ZC: funding acquisition. JX and QW: resources and supervision. All authors contributed to the article and approved the submitted version.

\section{FUNDING}

This work was supported by the National Natural Science Foundation of China (81971944 to JX), the CAMS Innovation Fund for Medical Sciences (2017-I2M-1-014 to QW), and the National Megaprojects of China for Major Infectious Diseases (2017ZX10304402 and 2018ZX10101001 to JX and 2018ZX10301103 to ZC).

\section{ACKNOWLEDGMENTS}

We acknowledge Preston Marx at the Aaron Diamond AIDS Research Center of the United States for kindly gifting the SIVmac239 strain. We also thank Haiquan Shang and Huiwu Li for the conduct of animal experiment.

CMV infection and increased in HIV-positive individuals on ART and lifestyle matched controls. PLoS One 12:e0183357. doi: 10.1371/journal.pone.0183357

Bordoni, V., Sacchi, A., Casetti, R., Cimini, E., Tartaglia, E., Pinnetti, C., et al. (2020). Impact of ART on dynamics of growth factors and cytokines in primary HIV infection. Cytokine 125:154839. doi: 10.1016/j.cyto.2019.154839

Brenchley, J. M., Price, D. A., Schacker, T. W., Asher, T. E., Silvestri, G., Rao, S., et al. (2006). Microbial translocation is a cause of systemic immune activation in chronic HIV infection. Nat. Med. 12, 1365-1371.

Cao, W., Mehraj, V., Kaufmann, D. E., Li, T., and Routy, J. P. (2016). Elevation and persistence of CD8 T-cells in HIV infection: the Achilles heel in the ART era. J. Int. AIDS Soc. 19:20697. doi: 10.7448/ias.19.1.20697

Casetti, R., Pinnetti, C., Sacchi, A., De Simone, G., Bordoni, V., Cimini, E., et al. (2017). HIV-specific CD8 T cells producing CCL-4 are associated with worse 
immune reconstitution during chronic infection. J. Acquir. Immune Defic. Syndr. 75, 338-344. doi: 10.1097/qai.0000000000001392

Chen, P., Su, B., Zhang, T., Zhu, X., Xia, W., Fu, Y., et al. (2017). Perturbations of monocyte subsets and their association with $\mathrm{T}$ helper cell differentiation in acute and chronic HIV-1-infected patients. Front. Immunol. 8:272. doi: 10.3389/ fimmu.2017.00272

Chong, H., Xue, J., Zhu, Y., Cong, Z., Chen, T., Wei, Q., et al. (2019). Monotherapy with a low-dose lipopeptide HIV fusion inhibitor maintains long-term viral suppression in rhesus macaques. PLoS Pathog. 15:e1007552. doi: 10.1371/ journal.ppat.1007552

Day, C. L., Kaufmann, D. E., Kiepiela, P., Brown, J. A., Moodley, E. S., Reddy, S., et al. (2006). PD-1 expression on HIV-specific T cells is associated with T-cell exhaustion and disease progression. Nature 443, 350-354.

Deeks, S. G. (2011). HIV infection, inflammation, immunosenescence, and aging. Annu. Rev. Med. 62, 141-155. doi: 10.1146/annurev-med-042909093756

Deeks, S. G., Lewin, S. R., and Havlir, D. V. (2013). The end of AIDS: HIV infection as a chronic disease. Lancet 382, 1525-1533. doi: 10.1016/s0140-6736(13) 61809-7

Dock, J. N., and Effros, R. B. (2011). Role of CD8 T cell replicative senescence in human aging and in HIV-mediated immunosenescence. Aging Dis. 2, 382-397.

Douek, D. C. (2013). Immune activation, HIV persistence, and the cure. Top. Antivir. Med. 21, 128-132.

Evans, V. A., van der Sluis, R. M., Solomon, A., Dantanarayana, A., Mcneil, C., Garsia, R., et al. (2018). Programmed cell death-1 contributes to the establishment and maintenance of HIV-1 latency. AIDS 32, 1491-1497. doi: 10.1097/qad.0000000000001849

Goepfert, P. A., Bansal, A., Edwards, B. H., Ritter, G. D. Jr., Tellez, I., Mcpherson, S. A., et al. (2000). A significant number of human immunodeficiency virus epitope-specific cytotoxic T lymphocytes detected by tetramer binding do not produce gamma interferon. J. Virol. 74, 10249-10255. doi: 10.1128/jvi.74.21. 10249-10255.2000

Goulder, P. J., Tang, Y., Brander, C., Betts, M. R., Altfeld, M., Annamalai, K., et al. (2000). Functionally inert HIV-specific cytotoxic T lymphocytes do not play a major role in chronically infected adults and children. J. Exp. Med. 192, 1819-1832. doi: 10.1084/jem.192.12.1819

Hansen, S. G., Vieville, C., Whizin, N., Coyne-Johnson, L., Siess, D. C., Drummond, D. D., et al. (2009). Effector memory $\mathrm{T}$ cell responses are associated with protection of rhesus monkeys from mucosal simian immunodeficiency virus challenge. Nat. Med. 15, 293-299. doi: 10.1038/nm.1935

Hansson, G. K. (2005). Inflammation, atherosclerosis, and coronary artery disease. N. Engl. J. Med. 352, 1685-1695. doi: 10.1056/nejmra043430

Hoffmann, M., Pantazis, N., Martin, G. E., Hickling, S., Hurst, J., Meyerowitz, J., et al. (2016). Exhaustion of activated CD8 T cells predicts disease progression in primary HIV-1 infection. PLoS Pathog. 12:e1005661. doi: 10.1371/journal. ppat. 1005661

Hua, S., Lécuroux, C., Sáez-Cirión, A., Pancino, G., Girault, I., Versmisse, P., et al. (2014). Potential role for HIV-specific CD38-/HLA-DR+ CD8+ T cells in viral suppression and cytotoxicity in HIV controllers. PLoS One 9:e101920. doi: 10.1371 /journal.pone. 0101920

Hunt, P. W. (2012). HIV and inflammation: mechanisms and consequences. Curr. HIV/AIDS Rep. 9, 139-147. doi: 10.1007/s11904-012-0118-8

Hunt, P. W., Brenchley, J., Sinclair, E., Mccune, J. M., Roland, M., Page-Shafer, K., et al. (2008). Relationship between $\mathrm{T}$ cell activation and CD4+ T cell count in HIV-seropositive individuals with undetectable plasma HIV RNA levels in the absence of therapy. J. Infect. Dis. 197, 126-133. doi: 10.1086/524143

Kaufmann, D. E., and Walker, B. D. (2008). Programmed death-1 as a factor in immune exhaustion and activation in HIV infection. Curr. Opin. HIV AIDS 3, 362-367. doi: 10.1097/coh.0b013e3282f9ae8b

Kostense, S., Ogg, G. S., Manting, E. H., Gillespie, G., Joling, J., Vandenberghe, K., et al. (2001). High viral burden in the presence of major HIV-specific CD8(+) T cell expansions: evidence for impaired CTL effector function. Eur. J. Immunol. 31, 677-686. doi: 10.1002/1521-4141(200103)31:3<677::aid-immu677>3.0. $\mathrm{co} ; 2-\mathrm{m}$

Kostense, S., Vandenberghe, K., Joling, J., Van Baarle, D., Nanlohy, N., Manting, E., et al. (2002). Persistent numbers of tetramer+ CD8(+) T cells, but loss of interferon-gamma + HIV-specific T cells during progression to AIDS. Blood 99, 2505-2511. doi: 10.1182/blood.v99.7.2505
Lichterfeld, M., Yu, X. G., Mui, S. K., Williams, K. L., Trocha, A., Brockman, M. A., et al. (2007). Selective depletion of high-avidity human immunodeficiency virus type 1 (HIV-1)-specific CD8+ T cells after early HIV-1 infection. J. Virol. 81, 4199-4214. doi: 10.1128/jvi.01388-06

Martínez-Zamudio, R. I., Dewald, H. K., Vasilopoulos, T., Gittens-Williams, L., Fitzgerald-Bocarsly, P., and Herbig, U. (2021). Senescence-associated $\beta$ galactosidase reveals the abundance of senescent CD8+ T cells in aging humans. Aging Cell 20:e13344.

Molina-Pinelo, S., Vallejo, A., Díaz, L., Soriano-Sarabia, N., Ferrando-Martínez, S., Resino, S., et al. (2009). Premature immunosenescence in HIV-infected patients on highly active antiretroviral therapy with low-level CD4 T cell repopulation. J. Antimicrob. Chemother. 64, 579-588. doi: 10.1093/jac/dkp248

Monti, D., Ostan, R., Borelli, V., Castellani, G., and Franceschi, C. (2017). Inflammaging and human longevity in the omics era. Mech. Ageing Dev. 165, 129-138. doi: 10.1016/j.mad.2016.12.008

Muenchhoff, M., Adland, E., Roider, J., Kløverpris, H., Leslie, A., Boehm, S., et al. (2019). Differential pathogen-specific immune reconstitution in antiretroviral therapy-treated human immunodeficiency virus-infected children. J. Infect. Dis. 219, 1407-1417. doi: 10.1093/infdis/jiy668

Naeger, D. M., Martin, J. N., Sinclair, E., Hunt, P. W., Bangsberg, D. R., Hecht, F., et al. (2010). Cytomegalovirus-specific T cells persist at very high levels during long-term antiretroviral treatment of HIV disease. PLoS One 5:e8886. doi: 10.1371/journal.pone.0008886

Ndhlovu, Z. M., Kamya, P., Mewalal, N., Kløverpris, H. N., Nkosi, T., Pretorius, K., et al. (2015). Magnitude and kinetics of CD8 $+\mathrm{T}$ cell activation during hyperacute HIV infection impact viral set point. Immunity 43, 591-604. doi: 10.1016/j.immuni.2015.08.012

Osuji, F. N., Onyenekwe, C. C., Ahaneku, J. E., and Ukibe, N. R. (2018). The effects of highly active antiretroviral therapy on the serum levels of pro-inflammatory and anti-inflammatory cytokines in HIV infected subjects. J. Biomed. Sci. 25:88.

Paiardini, M., and Müller-Trutwin, M. (2013). HIV-associated chronic immune activation. Immunol. Rev. 254, 78-101. doi: 10.1111/imr.12079

Pathai, S., Bajillan, H., Landay, A. L., and High, K. P. (2014). Is HIV a model of accelerated or accentuated aging? J. Gerontol. A Biol. Sci. Med. Sci. 69, 833-842. doi: 10.1093/gerona/glt168

Petrovas, C., Chaon, B., Ambrozak, D. R., Price, D. A., Melenhorst, J. J., Hill, B. J., et al. (2009). Differential association of programmed death-1 and CD57 with ex vivo survival of CD8+ T cells in HIV infection. J. Immunol. 183, 1120-1132. doi: 10.4049/jimmunol.0900182

Regidor, D. L., Detels, R., Breen, E. C., Widney, D. P., Jacobson, L. P., Palella, F., et al. (2011). Effect of highly active antiretroviral therapy on biomarkers of B-lymphocyte activation and inflammation. AIDS 25, 303-314. doi: 10.1097/ qad.0b013e32834273ad

Robbins, G. K., Spritzler, J. G., Chan, E. S., Asmuth, D. M., Gandhi, R. T., Rodriguez, B. A., et al. (2009). Incomplete reconstitution of T cell subsets on combination antiretroviral therapy in the AIDS Clinical Trials Group protocol 384. Clin. Infect. Dis. 48, 350-361. doi: 10.1086/595888

Sáez-Cirión, A., and Sereti, I. (2021). Immunometabolism and HIV-1 pathogenesis: food for thought. Nat. Rev. Immunol. 21, 5-19. doi: 10.1038/s41577-0200381-7

Schouten, J., Wit, F. W., Stolte, I. G., Kootstra, N. A., Van Der Valk, M., Geerlings, S. E., et al. (2014). Cross-sectional comparison of the prevalence of age-associated comorbidities and their risk factors between HIV-infected and uninfected individuals: the AGEhIV cohort study. Clin. Infect. Dis. 59, 1787-1797.

Sereti, I., Krebs, S. J., Phanuphak, N., Fletcher, J. L., Slike, B., Pinyakorn, S., et al. (2017). Persistent, albeit reduced, chronic inflammation in persons starting antiretroviral therapy in acute HIV infection. Clin. Infect. Dis. 64, 124-131. doi: 10.1093/cid/ciw683

Streeck, H., Jolin, J. S., Qi, Y., Yassine-Diab, B., Johnson, R. C., Kwon, D. S., et al. (2009). Human immunodeficiency virus type 1-specific CD8+ T-cell responses during primary infection are major determinants of the viral set point and loss of CD4+ T cells. J. Virol. 83, 7641-7648. doi: 10.1128/jvi.00182-09

van den Dries, L., Claassen, M. A. A., Groothuismink, Z. M. A., van Gorp, E., and Boonstra, A. (2017). Immune activation in prolonged cART-suppressed HIV patients is comparable to that of healthy controls. Virology 509, 133-139. doi: 10.1016/j.virol.2017.06.014 
van der Most, R. G., Murali-Krishna, K., Lanier, J. G., Wherry, E. J., Puglielli, M. T., Blattman, J. N., et al. (2003). Changing immunodominance patterns in antiviral CD8 T-cell responses after loss of epitope presentation or chronic antigenic stimulation. Virology 315, 93-102. doi: 10.1016/j.virol.2003.07.001

Vandergeeten, C., Fromentin, R., and Chomont, N. (2012). The role of cytokines in the establishment, persistence and eradication of the HIV reservoir. Cytokine Growth Factor Rev. 23, 143-149. doi: 10.1016/j.cytogfr.2012.05.001

Whitney, J. B., Lim, S. Y., Osuna, C. E., Kublin, J. L., Chen, E., Yoon, G., et al. (2018). Prevention of SIVmac251 reservoir seeding in rhesus monkeys by early antiretroviral therapy. Nat. Commun. 9:5429.

Wittkop, L., Bitard, J., Lazaro, E., Neau, D., Bonnet, F., Mercie, P., et al. (2013). Effect of cytomegalovirus-induced immune response, self antigen-induced immune response, and microbial translocation on chronic immune activation in successfully treated HIV type 1-infected patients: the ANRS CO3 Aquitaine Cohort. J. Infect. Dis. 207, 622-627.

Yero, A., Farnos, O., Rabezanahary, H., Racine, G., Estaquier, J., and Jenabian, M. A. (2019). Differential dynamics of regulatory T-cell and Th17 cell balance in Mesenteric lymph nodes and blood following early antiretroviral initiation during acute simian immunodeficiency virus infection. J. Virol. 93:e00371-19.
Youngblood, B., Noto, A., Porichis, F., Akondy, R. S., Ndhlovu, Z. M., Austin, J. W., et al. (2013). Cutting edge: prolonged exposure to HIV reinforces a poised epigenetic program for PD-1 expression in virus-specific CD8 T cells. J. Immunol. 191, 540-544. doi: 10.4049/jimmunol.1203161

Zhang, J. Y., Zhang, Z., Wang, X., Fu, J. L., Yao, J., Jiao, Y., et al. (2007). PD-1 upregulation is correlated with HIV-specific memory CD8+ T-cell exhaustion in typical progressors but not in long-term nonprogressors. Blood 109, 4671-4678. doi: 10.1182/blood-2006-09-044826

Conflict of Interest: The authors declare that the research was conducted in the absence of any commercial or financial relationships that could be construed as a potential conflict of interest.

Copyright (c) 2021 Tong, Cong, Tian, Zhang, Lu, Lu, Chen, Wang, Wei and Xue. This is an open-access article distributed under the terms of the Creative Commons Attribution License (CC BY). The use, distribution or reproduction in other forums is permitted, provided the original author(s) and the copyright owner(s) are credited and that the original publication in this journal is cited, in accordance with accepted academic practice. No use, distribution or reproduction is permitted which does not comply with these terms. 